\title{
Design and simulation of a piezoelectric transducer by finite element
}

\section{Diseño y simulación de transductor piezoeléctricos por elemento finito}

GALINDO-MENTLE, Margarita†*, BLAS-SÁNCHEZ, Luis Ángel, GONZALEZ-LICONA, Marlon and QUIROZ-RODRÍGUEZ, Adolfo

Universidad Tecnológica de Xicotepec de Juárez, Ingeniería en Mantenimiento Industrial, Av. Universidad Tecnológica No. 1000, Col. Tierra Negra, C.P. 73080, Cd. Xicotepec de Juárez, Pue., México

ID $1^{\text {st }}$ Author: Margarita, Galindo-Mentle / ORC ID: 0000-0001-5390-5960, Researcher ID Thomson: S-9202-2018, arXiv Author ID: Margarita G, CVU CONACYT ID: 160164

ID $1^{\text {st }}$ Co-author: Luis Ángel, Blas-Sánchez/ ORC ID: 0000-0003-3313-8551, Researcher ID Thomson: AAX-2475-2021, CVU CONACYT ID: 554052

ID $2^{\text {nd }}$ Co-author: Marlon, Licona-González / ORC ID: 0000-0001-7829-4457, Researcher ID Thomson: AAR-6259-2021, arXiv Author ID: marlon1987, CVU CONACYT ID: 1138370

ID $3^{\text {rd }}$ Co-author: Adolfo, Quiroz-Rodríguez / ORC ID: 0000-0002-9685-9455, Researcher ID Thomson: S-9189-2018, arXiv Author ID: adolfo-79, CVU CONACYT ID: 105471

DOI: $10.35429 /$ JSL.2021.24.8.1.6

Received March 30 2021; Accepted June 30, 2021

\begin{abstract}
One of the problems encountered in the manufacture of microstructures (MEMS) is the presence of residual stress caused by high temperatures during the manufacturing process. Residual stress generates deformation $(\varepsilon)$ in materials, which consists of fractional changes in their dimensions (linear, surface or volume). The application of amorphous materials in the manufacture of MEMS is carried out at a lower temperature than those used with Polysilicon, so it is an alternative to reduce residual stress. The objective of the work is to analyze the mechanical behavior of thin films of amorphous Silicon germanium (a-SiGe). The analysis is carried out through the behavior of springboard type resonant structures and using the simulation of the finite element method (FEM). The resonance frequency of a trampoline-type structure depends only on its geometric dimensions, its density, and its Young's modulus. The simulation results show that the behavior of the resonance frequency and the Young's Modulus of thin films of a-SiGe, placed on a trampolinetype structure changes linearly whit Germanium content.
\end{abstract}

ANSYS, Piezoelectric, Mechanical vibrations

\begin{abstract}
Resumen
Uno de los problemas que se tiene en la fabricación de microestructuras (MEMS) es la presencia de estrés residual ocasionado por las altas temperaturas durante el proceso de fabricación. El estrés residual genera deformación $(\varepsilon)$ en los materiales, la cual consiste en cambios fraccionarios en sus dimensiones (lineal, superficial o volumétrica). La aplicación de materiales amorfos en la fabricación de MEMS, se realiza a una temperatura menor que las usadas con el Polisilicio, por lo que resulta una alternativa para disminuir los esfuerzos residuales. El objetivo del trabajo es analizar el comportamiento mecánico de películas delgadas de Silicio germanio amorfo (a-SiGe). El análisis se realiza a través del comportamiento de estructuras resonantes tipos trampolín y usando la simulación del método de elementos finitos (MEF). La frecuencia de resonancia de una estructura tipo trampolín dependen solo de sus dimensiones geométricas, su densidad y su módulo de Young. Los resultados de la simulación muestran que el comportamiento de la frecuencia de resonancia y el Módulo de Young de películas delgadas de a-SiGe, colocadas sobre una estructura tipo trampolín cambia de forma lineal con el contenido de Germanio.
\end{abstract}

ANSYS, Piezoeléctrico, Vibraciones mecánicas

Citation: GALINDO-MENTLE, Margarita, BLAS-SÁNCHEZ, Luis Ángel, GONZALEZ-LICONA, Marlon and QUIROZRODRÍGUEZ, Adolfo. Design and simulation of a piezoelectric transducer by finite element. Journal Simulation and Laboratory. 2021, 8-24: 1-6

*Correspondence to Author (email: margarita.galindo@utxicotepec.edu.mx)

$\dagger$ Researcher contributing as first Author. 


\section{Introduction}

In the electronics industry, the manufacture of electronic devices depends on the characteristics of the materials and their design. Currently for the design of microsensors and microactuators using integrated circuit technology or microelectromechanical systems (MEMS), it is necessary to know the behavior of the materials used since their properties are critical in the performance and operation of manufactured devices (H. Baltes, et al, 2002).

In the manufacture of MEMS, many materials are deposited as thin films on a silicon substrate, which act as structural materials, insulating layer, electrical connection, among others (G. Craciun, 2002). For a long time the reasearch has been focused on the electrical properties of these materials (W. Hernández, etal, 2012). However, the development experienced by microelectromechanical systems (MEMS) has driven interest in knowing the mechanical properties, such as Young's Modulus of thin films, since it is an important parameter in determining the residual mechanical stresses in the structures (H. Guckel, 1985).

Young's modulus is a physical property, which quantifies the elasticity that a material has when it is subjected to a mechanical deformation caused by an external force. For characterizing mechanics of the materials there are different techniques, which require special equipment and also expensive. For example the technique by mechanical indentation instrumented (J.M. Meza, et al. 2008), the technique by Stress-Strain (Kuo-Shen Chen) and the Resonance Frequency Tracking Technique (Perez Ruiz S.J et al. 2008). Most characterization techniques require samples with certain characteristic. In this work a finite element analysis is performed in cantilever-type structures to determine Young's modulus in silicon-germanium amorphous films (a- SiGe).

\section{Methodology}

A mechanical structure when subjected to a periodic force can experience a phenomenon called resonance frequency. The resonance frequency occurs when the vibration periods of the applied force and the material coincide. The amplitude is maximum in its resonant state.
The resonant frequency of a cantilevertype structure depends on its geometric dimensions, its density and its Young's modulus, based on the Euler-Bernuilli model (Singiresu S. Rao). Of the analysis equivalent to the behavior of a forced damped resonator mechanical system, and according to the moment of inertia of the lever area, the resonance frequency is expressed as Equation 1 (S. Alcantara et, al. 2010).

$$
f_{\text {res }}=0.1604 \cdot \sqrt{\frac{E \cdot\left(1-v^{2}\right)}{\rho}} \cdot\left(\frac{h}{l^{2}}\right)
$$

Where $\mathrm{E}$ is the Young's modulus of the material, $v$ the Poisson's ratio, the volumetric density $\rho(\rho=m / l . h . w)$, the thickness $h, w$ the width of the plate and $l$ the length of the plate.

By depositing a thin film of on the surface of the cantilever structure, it causes an increase in its mass $\Delta m$, which generates a change in the resonant frequency $\left(\Delta F_{\text {res }}=f_{0}^{\prime 2}-f_{0}^{2}\right)$.

From equation 1, we can determine the amount of mass deposited on the cantilever. The increase of mass is expressed by equation 2 .

$\Delta m=0.0261 . E .\left(1-v^{2}\right) \frac{W \cdot h^{3}}{l^{3}}\left\lceil\frac{1}{f_{0}^{\prime 2}}-\frac{1}{f_{0}^{2}}\right\rceil$

Young's modulus (E) of the material can be solved from equation 2 , being expressed with the equation 3 .

$E=\frac{\Delta m}{0.0261 \cdot\left(1-v^{2}\right)} \cdot \frac{l^{3}}{W \cdot h^{3}}\left(f_{0}^{\prime 2}-f_{0}^{2}\right)$

Where $f_{0}$ is the resonant frequency of the cantilever and $f_{0}^{\prime}$ belongs to the frequency of the cantilever with the thin film.

The main applications of cantilever-type structures are based on the equations above, and can be used as a mechanical vibration sensor.

In this work we will analyze the simulation of the dynamic behavior of amorphous SiliconGermanium (a-SiGe) thin films, on a cantilevertype piezoelectric structure. To perform the simulations using the finite element method (FEM), the ANSYS® Multiphysics software was used (Gockenbach, S. M. 2006). 
This tool is very versatile for the simulation of microstructures; its analysis allows us to obtain an approximate numerical solution on the behaviour. To carry out the simulations, it is necessary to know the material properties: electrical, mechanical and thermal.

The values of the materials must be entered using the micro meter kilogram second $(\mu \mathrm{MKS})$ system. The analysis carried out is of the structural-thermal-electrical type, for which the SOLID98 element has been selected (Liu, G. R.; Quek, S. S. 2003). Figure 1, shows the cantilever mesh with 3,884 elements and the view of the mesh in the rectangular plate.
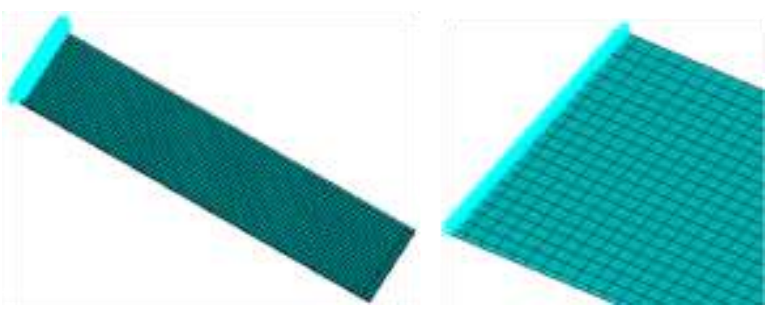

Figure 1 Cantilever meshing whit Solid98 elements

\section{Results}

For the simulations, it is considered that the cantilever is embedded at one end, that it does not move in any direction, they have a length $l=$ $5.8 \mathrm{~mm}$, a width $w=1.54 \mathrm{~mm}$, thickness $h=$ $0.55 \mathrm{~mm}$, its Young's Modulus is $E=83 \mathrm{GPa}$, Poisson's ratio $v=0.32$ and a volumetric density $\rho=7700 \mathrm{Kg} / \mathrm{m}^{3}$. In the upper part of the trampoline a $3 \mu \mathrm{m}$ thin film is simulated considering the properties of amorphous Silicon and Germanium. In Figure 2 a), the design of the piezoelectric cantilever (PZT) is shown, Figure 2 b) shows the thin film of the $3 \mu \mathrm{m}$ amorphous material.

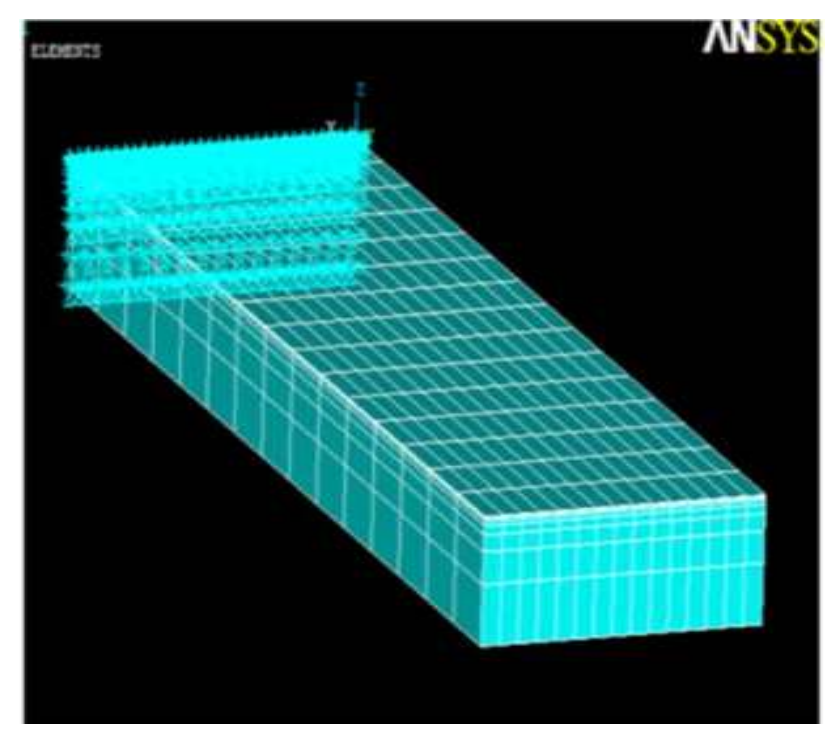

a)

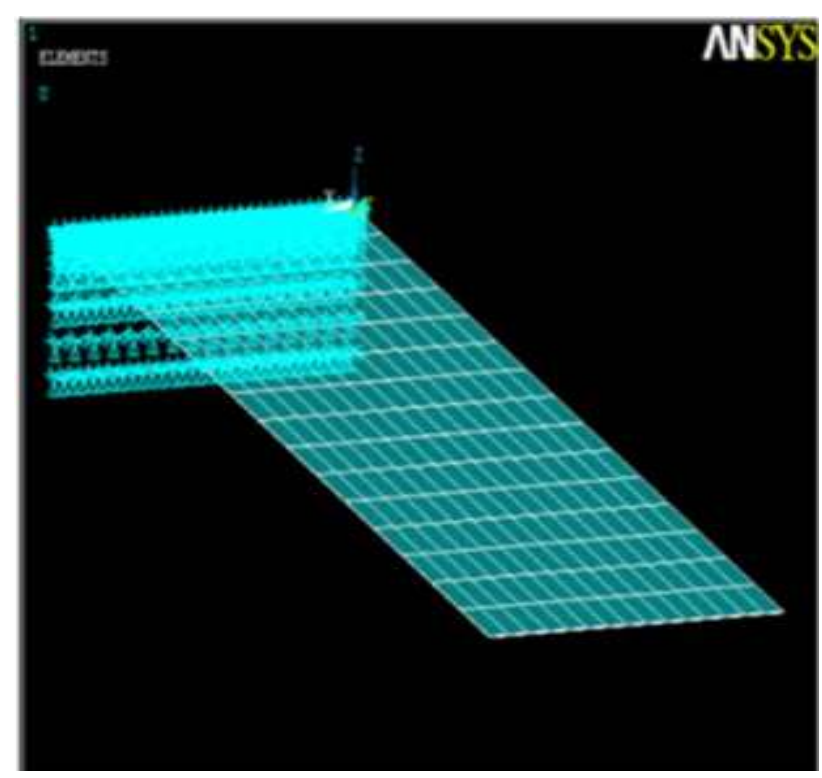

b)

Figure 2 a) Piezoelectric Cantilever (PZT), b) thin film of amorphous material

The simulation results for the piezoelectric trampoline show its first vibration mode located at $11922.3 \mathrm{~Hz}$, figure 3 .

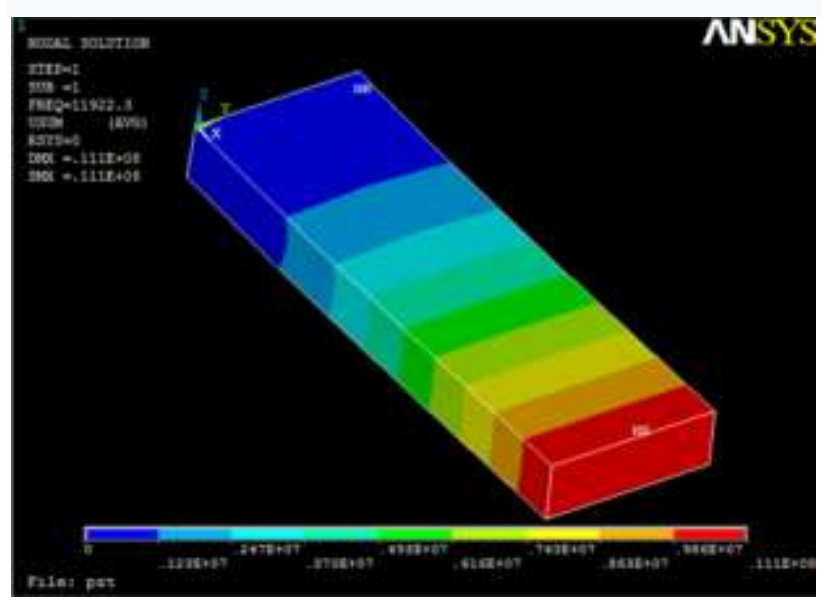

Figure 3 Piezoelectric Cantilever (PZT) resonance frequency $11922.3 \mathrm{~Hz}$

By placing the $3 \mu \mathrm{m}$ thin film on the surface of the PZT trampoline, it causes a shift in its frequency. Figure 4 shows the resonance frequency response at $16380.6 \mathrm{~Hz}$ generated by the thin film of Amorphous Silicon (a-Si). 


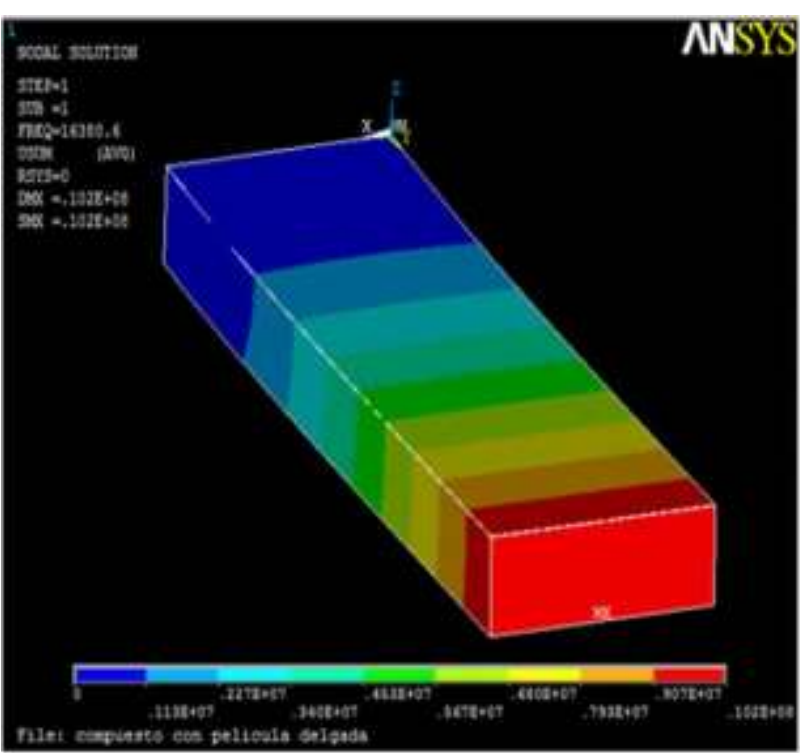

Figure 4 Resonance frequency of cantilever PZT whit thin film of Amorphous Silicon (a-Si) $16380.6 \mathrm{~Hz}$

For the simulation of thin films of amorphous Silicon, its mechanical properties are considered and the concentrations of germanium are varied. Table 1 shows the mechanical properties of amorphous Silicon and Germanium.

\begin{tabular}{|c|c|c|}
\hline Mechanical propeties & a-Si:H & a-Ge:H \\
\hline $\begin{array}{ll}\text { Coefficient } & \text { of } \\
\text { expansion } & \end{array}$ & $2.33 \times 10^{-6} \mathrm{~K}^{-}$ & $5,75 \times 10^{-6} \mathrm{~K}^{-1}$ \\
\hline Density & $2330 \mathrm{~kg} / \mathrm{m}^{3}$ & $5323 \mathrm{~kg} / \mathrm{m}^{3}$ \\
\hline $\begin{array}{ll}\text { Young's } & \text { Module } \\
(\mathrm{GPa}) & \end{array}$ & 150 & 110 \\
\hline Poisson's ratio & 0.28 & 0.25 \\
\hline Thermal conductivity & $148 \mathrm{~W} /(\mathrm{K} . \mathrm{m})$ & 59,9W/(K.m) \\
\hline Stress $\sigma(\mathrm{MPa})$ & 50T-500C & 800T-800C \\
\hline $\begin{array}{ll}\text { Compressive } & \text { Stress } \\
(\mathrm{Pa}) & \end{array}$ & $3.667 \mathrm{e}^{9}$ & $5.982 \mathrm{e}^{8}$ \\
\hline Tensile Stress $(\mathrm{Pa})$ & 509832 & $3.233 \mathrm{e}^{7}$ \\
\hline Energy Gap Eg (eV) & 1.8 & 0.78 \\
\hline Reflection index (n) & 3.4 & 4 \\
\hline
\end{tabular}

Table 1 Mechanical properties of amorphous materials (J. Lee, C-J. Kim,2000)

The results are shown in figure 5. For an Amorphous Silicon-germanium film with a concentration of $75 \%$ and $25 \%$ (a-Si $\mathrm{Si}_{75 \%} \mathrm{Ge}_{25 \%}$ ), a Frequency of $16333.3 \mathrm{~Hz}$ was obtained.

Figure $5 \mathrm{~b}$ ) shows a resonance frequency of $16290.7 \mathrm{~Hz}$ for a thin film of the Amorphous Silicon-germanium alloy with a concentration of $50 \%$ and $50 \%$ (a-Si $\left.50 \% \mathrm{Ge}_{50 \%}\right)$.

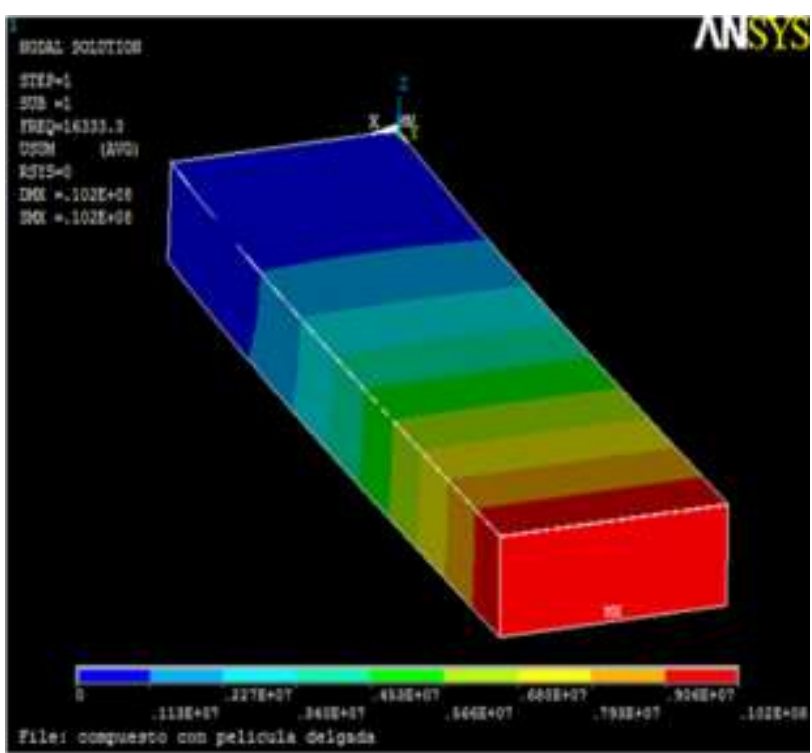

a)

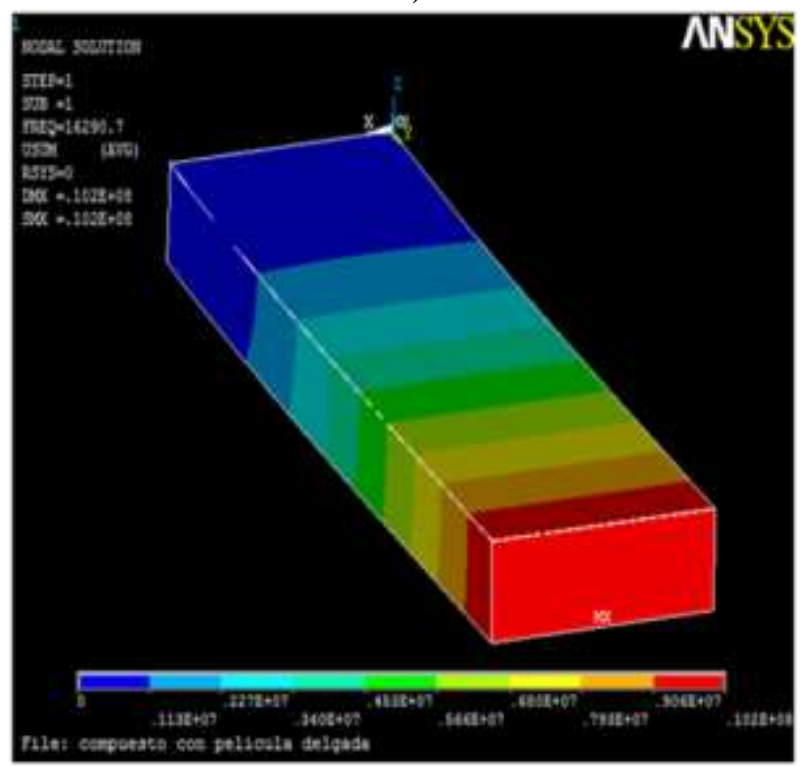

b)

Figure 5 Piezoelectric cantilever resonance frequency (PZT) whit amorphous Silicon-germanium thin film. a) For a-Si ${ }_{75 \%} \mathrm{Ge}_{25 \%}$ film a resonance Frequency of $16333.3 \mathrm{~Hz}$ was obtained, b) shows a resonance frequency of $16290.7 \mathrm{~Hz}$ for a thin film of a-Si $i_{50 \%} \mathrm{Ge}_{50 \%}$.

The calculated resonance frequency of the PZT cantilever with amorphous a-SiGe films, using the finite element method (FEM) in the ANSYS ${ }^{\circledR}$ software, is shown in table 2.

Young's Modulus of the a-SiGe films is calculated using equation 3 , where $f_{0}$ is the resonance frequency of the piezoelectric cantilever and $f_{0}^{\prime}$ belongs to the frequency of the piezoelectric cantilever PZT with the films of the Silicon-Germanium material amorphous (aSiGe). 


\begin{tabular}{|l|r|r|}
\multicolumn{1}{|c}{ Material } & \multicolumn{1}{c}{$\begin{array}{c}\text { Frequency } \\
\text { (KHz) }\end{array}$} & $\begin{array}{c}\text { Young's Modulus } \\
\text { (GPa) }\end{array}$ \\
\hline PZT & 8.7 & 8.3 \\
\hline PZT(a-Si:H) & 16.38 & 150 \\
\hline PZT(a-Ge:H) & 16.17 & 110 \\
\hline PZT(a-Si $\left.75 \% \mathrm{Ge}_{25 \%}: \mathrm{H}\right)$ & 16.33 & 140 \\
\hline PZT(a-Si50\%Ge50\%:H) & 16.29 & 130 \\
\hline PZT(a-Si $\left.25 \% \mathrm{Ge}_{75 \%}: \mathrm{H}\right)$ & 16.24 & 120 \\
\hline
\end{tabular}

Table 2 Resonance frequency behaviour of cantilever PZT whit thin a-SiGe films

\section{Conclusions}

The results obtained by simulation in ANSYS, shows an indirect way to measure the Young's modulus of thin films. If the properties of the materials are known, it is possible to have a more precise analysis of the mechanical behavior of the structures.

For this work, the mechanical properties of amorphous silicon and germanium were considered. The results obtained from the simulation in ANSYS show a linear behavior of the Young's Modulus when varying the germanium content in the thin films of amorphous Silicon.

\section{References}

Ariza, F. H. G., \& Rodríguez, G. M. (2021). Fortalecimiento de la convivencia mediante el Contact Improvisatión: una experiencia desde la educación media: Strengthening coexistence through Contact Improvisation: an experience from middle school. Noria Investigación Educativa, 2(8).

Elemento para la simulación de campos acoplados en tres dimensiones3-D. http://www.kxcad.net/ansys/ANSYS/ansyshelp/ Hlp_E_SOLID227.html Acceso: Marzo (2009).

Gockenbach, S. M. Understanding and Implementing the Finite Element Method. Society for Industrial and Applied Mathematics (2006).

G. Craciun, H. Yang, W. Van Zeijl, L. Pakula, A. Blauw, E. Van der Drift, J. French, Single step cryogenic SF6/O2 Plasma etching process for the development of inertial devices. Proceedings on Semiconductors Sensors. Fabrication and characterization (2002) 612615.
H. Baltes, O. Brand, A. Hierlemann, D. Lange, C. Hagleitner, CMOS MEMS present and future, International conference on Micro Electro Mechanical Systems (2002) 459-466.

H. Guckel, T. Randazzo, D.Burns, A simple technique for the determination of mechanical strain in thin films with applications to polysilicon. J. Appl. Phys. (1985) 57(5), pp. 1671- 1675.

J. Lee, C-J. Kim. Surface-tension-driven microactuation based on continuous electrowetting. J. Micromech. System, 9-2, pp. 171-180, (2000).

J.M. Meza, E. E. Franco, M. Farias, F. Buiochi, R. M. Souza, J. Cruz, Medición del módulo de elasticidad en materiales de ingeniería utilizando la técnica de indentación instrumentada y de ultrasonido, Revista De Metalurgia, 44, EneroFebrero, 2008, 52-65.

Kuo-Shen Chen, Techniques in Residual Stress Measurement for MEMS and Their Applications, Department of Mechanical Engineering, National Cheng-Kung University, Tainan, Taiwan, 70101, R.O.C.

Liu, G. R.; Quek, S. S. The Finite Element Method: A practical course. Butterworth Heinemann (2003).

Lara Osuna, R. (2021). Aplicaciones de la Projection-Based Augmented Reality en la enseñanza de las Artes Visuales a partir de las propuestas didácticas de José Val del Omar: una Investigación Educativa Basada en las Artes.

N. Cuadrado, D. Casellas, J. Caro, L. Llanes, Caracterización Mecánica Mediante La Técnica De Nanoindentación De Partículas Duras, Anales de Mecánica de la Fractura 26, Vol. 2, 2009. 566-571.

Perez Ruiz, S.J et al. Optical sensing technique for Young's modulus measurements in piezoelectric materials, Revista mexican de Fisica. [online]. 2008, vol.54, n.3, pp. 253-256. ISSN 0035-001X.

Singiresu S. Rao, Vibraciones Mecánicas, 5ta Ed, PEARSON, 2012, ISBN:987-607-32-09526. 
S. Alcantara-Iniesta, B. S. Soto-Cruz, J. Pérez, W. Calleja-Arriaga, G. Romero-Paredes, M. Duarte, Margarita Galindo-Mentle, Resonador de masa: desarrollo y metodos de medición. Superficies y Vacio, 23, (2010), 1-5.

W. Hernández, I. Zaldivar, C. Zúñiga, A. Torres, C. Reyes, A. Itzmoyol. Optical and compositional properties of amorphous silicongermanium films by plasma processing for integrated photonics. Optical Materials Express. 2 (2012) 358-370. 